\title{
Hubungan Kadar Prokalsitonin dan Kultur Bakteri dengan Tingkat Keparahan Pneumonia pada Anak
}

\author{
Sri Utami Suwarto, Eddy Fadlyana, Cissy Kartasasmita \\ Departemen Ilmu Kesehatan Anak Fakultas Kedokteran Universitas Padjadjaran/Rumah Sakit Hasan Sadikin, Bandung
}

\begin{abstract}
Latar belakang. Di negara berkembang, pneumonia merupakan penyebab utama kesakitan dan kematian pada bayi dan balita. Penelitian sebelumnya menemukan prokalsitonin dapat menggambarkan keparahan pneumonia pada anak. Dilaporkan juga kultur bakteri positif lebih sering ditemukan pada pneumonia berat dengan komplikasi.

Tujuan. Menentukan hubungan kadar prokalsitonin dan kultur bakteri dengan tingkat keparahan pneumonia.

Metode. Penelitian potong lintang yang dilaksanakan dari bulan September 2014 hingga Januari 2015 di RSUP Dr. Hasan Sadikin Bandung. Dilibatkan 61 anak berusia 1 bulan hingga 5 tahun. Subjek terdiri atas 30 anak pneumonia berat dan 31 anak pneumonia. Pemeriksaan prokalsitonin dilakukan dengan Elecsys BRAHMS PCT. Kultur darah diperiksa dengan mesin BACTEC 9050, jika hasilnya positif bakteri kemudian dibiakkan dalam media agar McConkey atau agar darah. Data hasil penelitian diuji dengan Mann Whitney dan chi-square.

Hasil. Nilai median PCT pneumonia berat $0,69 \mathrm{ng} / \mathrm{mL}$ dan pneumonia $0,075 \mathrm{ng} / \mathrm{mL}$, dengan nilai $\mathrm{p}<0,001$. Hasil kultur positif ditemukan 5 dari 30 pada pneumonia berat dan 10 dari 31 pada pneumonia, dengan nilai $p=0,157$.

Kesimpulan. Keparahan pneumonia berhubungan dengan kadar prokalsitonin dan tidak berhubungan dengan hasil kultur bakteri. Sari Pediatri 2015;17(4):261-6.
\end{abstract}

Kata kunci: keparahan pneumonia, kultur bakteri, prokalsitonin

\section{Relationship of Procalcitonin Level and Bacterial Culture with Pneumonia Severity Level in Children}

\author{
Sri Utami Suwarto, Eddy Fadlyana, Cissy Kartasasmita
}

Background. Pneumonia is the leading cause of morbidity and mortality in infants and children under five in developing countries. Previous studies finds that procalcitonin can predict the severity of pneumonia in children. It is also reported that positive bacterial culture is found more often in severe pneumonia with complications.

Objective. The aim of this study is to determine the relationship of procalcitonin and bacterial culture with pneumonia severity.

Methods. This is a cross-sectional study conducted from September 2014 to January 2015 involving 61 children in Hasan Sadikin hospital emergency room diagnosed with pneumonia age more than 1 month to 5 years old. Subject consisted of 31 pneumonia and 30 severe pneumonia. Procalcitonin examination was carried out by Elecsys BRAHMS PCT. Blood culture was done by incubating the blood sample in BACTEC 9050 machine, positive blood culture was then cultured using McConkey or blood agar. Correlation analysis was using Mann Whitney test and chi squared.

Result. The study showed that the median procalcitonin levels for severe pneumonia were $0.69 \mathrm{ng} / \mathrm{mL}$ and for pneumonia were $0.075 \mathrm{ng} / \mathrm{mL}$, p value was $<0.001$. Positive blood culture for severe pneumonia was 5 out of 30 and for pneumonia was 10 out of 31 , p value was 0.157 .

Conclusion. There is a relationship between procalcitonin levels and pneumonia severity while positive blood culture is found not related with pneumonia severity. Sari Pediatri 2015;17(4):261-6.

Keywords: procalcitonin, childhood pneumonia, pneumonia severity

\footnotetext{
Alamat korespondensi: Dr. Sri Utami Suwarto. Departemen Ilmu Kesehatan Anak Fakultas Kedokteran Universitas Padjadjaran/Rumah Sakit Dr. Hasan Sadikin Jl. Pasteur No.38 Bandung 40163. Tel +62-22-3035957. E-mail: kikasriutami@yahoo.com
} 
$\mathrm{P}$ neumonia pada anak berusia kurang dari lima tahun masih merupakan penyebab utama kesakitan dan kematian pada anak di dunia. Diperkirakan 95\% kasus pada anak terjadi di negara berkembang. Setiap tahunnya, terjadi 150,7 juta kasus pneumonia baru, 11-20 (7\%-13\%) juta di antaranya merupakan berat sehingga membutuhkan perawatan. ${ }^{1}$

Prokalsitonin (PCT) adalah substansi mirip sitokin yang dilepaskan oleh berbagai sel parenkim sebagai respons terhadap toksin mikrob dan beberapa mediator proinflamasi inang tertentu. ${ }^{2}$ Assicot $\mathrm{dkk}^{3}$ menemukan prokalsitonin serum cenderung meningkat pada infeksi sistemik oleh bakteri, sedangkan untuk infeksi yang bersifat terlokalisasi dan disebabkan oleh virus jarang meningkat. Don $\mathrm{dkk}^{4}$ menemukan kadar prokalsitonin pada pasien pneumonia berat yang membutuhkan perawatan jauh lebih tinggi (median 17,8 dibanding dengan $0,72 \mathrm{ng} / \mathrm{mL}$, nilai $\mathrm{p}<0,01)$. Boussekey $\mathrm{dkk}^{5} \mathrm{dan}$ Tseng $\mathrm{dkk}^{6}$ menemukan bila kadar prokalsitonin serum lebih tinggi pada hari ke-3 perawatan maka prognosis akan lebih buruk.

Pemeriksaan kultur darah direkomendasikan untuk semua pasien yang secara klinis didiagnosis pneumonia. Pemeriksaan kultur darah sering kali negatif pada sebagian besar kasus. Penelitian Shah dkk, Williams dkk, Cham dkk, dan Myers dkk menemukan kultur positif hanya ditemukan pada $2,1 \%, 3 \%, 6 \%$, dan $7 \%$ kasus pneumonia. ${ }^{7-10}$ Cilloniz $\mathrm{dkk}^{11}$ dan Paganin $\mathrm{dkk}^{12}$ menemukan kultur positif pada 39\%-41\% pasien pneumonia berat dengan komplikasi. Penelitian Shah ${ }^{7}$ dkk dan Myers dkk ${ }^{10}$ melaporkan bakteremia lebih sering ditemukan pada pneumonia berat dengan komplikasi.

Pemeriksaan prokalsitonin masih jarang dilakukan pada kasus pneumonia anak di Indonesia. Sementara itu, kultur darah yang rutin dikerjakan jarang menemukan kultur positif. Penelitian ini bertujuan menentukan hubungan kadar prokalsitonin dan kultur bakteri dengan tingkat keparahan pneumonia di RSUP Dr. Hasan Sadikin Bandung. Penelitian telah disetujui oleh Komite Etik RSUP Dr. Hasan Sadikin dan orangtua telah menandatangani surat persetujuan (informed consent).

\section{Metode}

Penelitian analitik observasional dengan rancangan potong lintang. Pemilihan semua subjek penelitian dilakukan secara berurutan hingga memenuhi jumlah sampel yang telah dihitung. Subjek penelitian adalah pasien dengan diagnosis pneumonia yang datang ke Unit Gawat Darurat RSUP Dr. Hasan Sadikin Bandung berusia antara 1 bulan sampai dengan 5 tahun periode September 2014 sampai dengan Januari 2015. Sampel dikelompokkan menjadi pneumonia dan pneumonia berat berdasarkan kriteria WHO tahun $2013 .^{13}$

Klasifikasi pneumonia menurut WHO tahun 2013 terbagi menjadi pneumonia dan pneumonia berat. Pneumonia berdasarkan gejala, yaitu terdapat napas yang cepat berdasarkan usia dan tarikan dinding dada, sedangkan pada pneumonia berat, yaitu saturasi oksigen $<90 \%$ atau sianosis sentral, gangguan pernapasan (grunting dan retraksi berat), gejala bahaya seperti tidak mampu minum, letargi/penurunan kesadaran, dan kejang.

Kriteria inklusi adalah anak berusia 1 bulan sampai dengan 5 tahun dan dengan diagnosis pneumonia. Kriteria eksklusi adalah pasien yang secara klinis memiliki gejala penyakit infeksi penyerta selain pneumonia, seperti diare dan infeksi saluran kemih serta kelainan lainnya yang dapat meningkatkan marker inflamasi, seperti riwayat penyakit autoimun, keganasan, atau luka bakar.

Sampel untuk pemeriksaan prokalsitonin dan kultur darah diambil di IGD anak RSUP Dr Hasan Sadikin (RSHS) sebanyak $5 \mathrm{~mL}$ oleh perawat terlatih. Pemeriksaan prokalsitonin dilakukan dengan Elecsys BRAHMS PCT dengan metode electrochemiluminescence immunoassay. Sampel pemeriksaan adalah serum darah $2 \mathrm{~mL}$ yang disimpan dalam tabung pemeriksaan standar. Sampel dibekukan pada suhu $-20^{\circ} \mathrm{C}$ untuk diperiksa setelah semua sampel terkumpul. Tiga $\mathrm{mL}$ darah dimasukkan ke dalam botol BACTEC dan segera dikirim ke laboratorium Patologi Klinik RSHS dalam waktu kurang dari 2 jam. Botol BACTEC diinkubasi selama 5 hari dengan mesin BACTEC 9050 sesuai protokol yang berlaku di laboratorium patologi klinik RSHS, pada hasil kultur positif dilakukan proses lebih lanjut untuk isolasi bakteri dalam agar McConkey atau agar darah. Koloni bakteri yang tumbuh diidentifikasi sampai level spesies.

Hasil penelitian untuk data kategori diuji dengan chi-kuadrat, sedangkan untuk menguji hubungan kadar prokalsitonin dengan keparahan pneumonia menggunakan uji Mann Whitney. 


\section{Hasil}

Selama periode penelitian didapat 105 pasien anak dengan diagnosis pneumonia. Subjek yang memenuhi kriteria penelitian 68 subjek, terdiri atas 36 anak dengan pneumonia dan 32 dengan pneumonia berat. Sampel darah yang lisis 5 pada kelompok pneumonia dan 2 pada kelompok pneumonia berat sehingga jumlah subjek 61 orang.

Karakteristik subjek penelitian tertera pada Tabel 1, meliputi usia anak saat penelitian, jenis kelamin, keberadaan perokok di rumah, status ekonomi, status gizi, riwayat antibiotik, dan riwayat ASI. Tidak ada perbedaan yang bermakna antara pneumonia berat dan pneumonia.

Hasil uji beda menggunakan uji Mann Whitney kadar prokalsitonin antara pneumonia berat dan pneumonia berbeda bermakna $(p<0,001)$. Selanjutnya, dihitung besarnya risiko rasio prevalens diperoleh hasil (IK 95\%) 4,1 (2,39-7,03); artinya jika penderita pneumonia memiliki kadar prokalsitonin $0,690 \mathrm{ng} / \mathrm{mL}$ maka risiko terjadi pneumonia berat adalah 4,1 kali bila dibanding dengan penderita pneumonia yang memiliki kadar prokalsitonin 0,075 ng/mL (Tabel 2).

Hasil kultur negatif kelompok pneumonia berjumlah 21 dari 30 orang, sementara pneumonia berat 25 dari 31 orang. Hasil kultur positif yang terdiagnosis pneumonia ditemukan 10 dari 31 orang dan pneumonia berat sebesar 5 dari 30 orang. Berdasarkan analisis menggunakan uji chi-kuadrat didapatkan nilai $\mathrm{p}=0,157$ (Tabel 3).

Tabel 4 menyajikan gambaran jenis bakteri yang ditemukan pada penderita pneumonia dan pneumonia berat. Ditemukan 6 jenis bakteri, tiga jenis pada penderita pneumonia dan empat jenis pada penderita pneumonia berat.

Tabel 1. Subjek penelitian yang berhubungan dengan keparahan pneumonia

\begin{tabular}{|c|c|c|c|}
\hline \multirow{2}{*}{ Karakteristik } & \multicolumn{2}{|c|}{ Keparahan pneumonia } & \multirow{2}{*}{$\mathrm{p}^{*}$} \\
\hline & Pneumonia berat $(\mathrm{n}=30)$ & Pneumonia $(n=31)$ & \\
\hline \multicolumn{4}{|l|}{ Usia (bulan) } \\
\hline$\leq 12$ & 25 & 23 & 0,642 \\
\hline $13-36$ & 4 & 7 & \\
\hline $37-60$ & 1 & 1 & \\
\hline Median & 5 & 5 & \\
\hline Rentang & $1-48$ & $1-50$ & \\
\hline \multicolumn{4}{|l|}{ Jenis kelamin } \\
\hline Laki-laki & 16 & 20 & 0,375 \\
\hline Perempuan & 14 & 11 & \\
\hline \multicolumn{4}{|l|}{ Perokok di rumah } \\
\hline Ada & 20 & 2 & 0,929 \\
\hline Tidak ada & 10 & 10 & \\
\hline \multicolumn{4}{|l|}{ Status ekonomi } \\
\hline Tidak mampu & 23 & 23 & 0,823 \\
\hline Mampu & 7 & 8 & \\
\hline \multicolumn{4}{|l|}{ Status gizi } \\
\hline Malnutrisi $(\mathrm{BB} / \mathrm{PB}<-2 \mathrm{SD})$ & 11 & 8 & 0,360 \\
\hline Tidak ada malnutrisi & 19 & 23 & \\
\hline \multicolumn{4}{|c|}{ Riwayat antibiotik (sebelum masuk IGD) } \\
\hline Tidak pernah & 16 & 20 & 0,375 \\
\hline Pernah & 14 & 11 & \\
\hline \multicolumn{4}{|l|}{ Riwayat ASI } \\
\hline Tanpa ASI & 10 & 8 & 0,519 \\
\hline $\mathrm{ASI}_{ \pm}$susu formula & 20 & 23 & \\
\hline
\end{tabular}

*Uji Pearson chi-square 
Sri Utami Suwarto dkk: Hubungan kadar PCT dan kultur bakteri dengan tingkat keparahan pneumonia

Tabel 2. Hubungan prokalsitonin dengan keparahan pneumonia

\begin{tabular}{|c|c|c|c|c|}
\hline & \multicolumn{2}{|c|}{ Keparahan pneumonia } & \multirow[b]{2}{*}{$\mathrm{p}^{*}$} & \multirow[b]{2}{*}{$\begin{array}{c}\mathrm{RP} \\
(\mathrm{IK} 95 \%\end{array}$} \\
\hline & $\begin{array}{l}\text { Pneumonia berat } \\
\qquad(\mathrm{n}=30)\end{array}$ & $\begin{array}{l}\text { Pneumonia } \\
\quad(\mathrm{n}=31)\end{array}$ & & \\
\hline $\begin{array}{l}\text { Median } \\
\text { Rentang }\end{array}$ & $\begin{array}{c}0,690 \\
0.149-94,58\end{array}$ & $\begin{array}{c}0,075 \\
0,029-0,183\end{array}$ & $<0,001$ & $\begin{array}{c}4,1 \\
(2,4-7)\end{array}$ \\
\hline
\end{tabular}

Keterangan: * Uji Mann Whitney

Tabel 3. Hubungan hasil kultur dengan keparahan pneumonia

\begin{tabular}{llcccc}
\hline & & \multicolumn{2}{c}{ Keparahan pneumonia } & & \multirow{2}{*}{ Total } \\
\cline { 3 - 4 } & & $\begin{array}{c}\text { Pneumonia berat } \\
(\mathrm{n}=30)\end{array}$ & $\begin{array}{c}\text { Pneumonia } \\
(\mathrm{n}=31)\end{array}$ & & $\mathrm{p}^{*}$ \\
\hline Hasil & Positif & 5 & 10 & 15 & 0,157 \\
Kultur & Negatif & 25 & 21 & 46 & 0,157 \\
\hline
\end{tabular}

Keterangan: *Uji chi-kuadrat

Tabel 4. Jenis bakteri pada pneumonia

\begin{tabular}{lcc}
\hline Jenis bakteri & $\begin{array}{r}\text { Pneumonia } \\
\text { berat }(\mathrm{n}=30)\end{array}$ & $\begin{array}{c}\text { Pneumonia } \\
(\mathrm{n}=31)\end{array}$ \\
\hline Staphylococcus hominis & 2 & 8 \\
Staphylococcus hemoliticus & - & 1 \\
Enterococus faecium & 1 & - \\
Leclercia adecarboxylata & 1 & - \\
Pseudomonas flouroscens & 1 & - \\
Klebsiella pneumoniae & - & 1 \\
\hline Total & 5 & 10 \\
\hline
\end{tabular}

\section{Pembahasan}

Hasil penelitian menunjukkan bahwa terdapat hubungan antara keparahan pneumonia dan kadar prokalsitonin. Pada pneumonia, peningkatan kadar prokalsitonin disebabkan toksin mikrob dan beberapa mediator proinflamasi, seperti IL-1 $\beta$, TNF- $\alpha$, dan IL-6 yang menimbulkan peradangan sel parenkim sehingga menghasilkan substansi mirip sitokin yang dikenal sebagai prokalsitonin. Semakin berat peradangan yang terjadi maka semakin tinggi pula kadar prokalsitonin yang dihasilkan. Penelitian Don dkk, Boussekey dkk, Tseng dkk, dan Okimoto dkk juga menemukan kadar prokalsitonin serum semakin besar pada pasien pneumonia berat dengan prognosis yang lebih buruk. 4-6,14

Kami menemukan hasil kultur tidak berhubungan dengan keparahan pneumonia. Hasil kultur positif pasien dengan diagnosis pneumonia ditemukan 10 dari
31 orang, sedangkan pneumonia berat 5 dari 30 orang. Hasil tersebut secara statistik tidak berbeda bermakna. Cilloniz $\mathrm{dkk}^{11}$ dan Paganin $\mathrm{dkk}^{12}$ menemukan kultur positif pada 39\%-41\% pasien pneumonia berat dengan komplikasi.

Kami menemukan 3 jenis bakteri pada pneumonia dan 4 pada pneumonia berat. Jenis bakteri pada pneumonia, yaitu Staphylococcus hominis, Staphylococcus hemoliticus, dan Klebsiella pneumoniae, sedangkan pada pneumonia berat, yaitu Staphylococcus hominis, Enterococcus faecium, Leclercia adecarboxylata, dan Pseudomonas flourescens.

Cilloniz $\mathrm{dkk}^{11}$ meneliti 3523 pasien yang secara klinis terdiagnosis pneumonia komunitas, kultur bakteri berhasil ditemukan pada 1463 (41\%) pasien dan terbanyak ditemukan adalah $S$. pneumoniae diikuti oleh bakteri yang jarang didapat, gabungan, dan virus. Frekuensi temuan S. pneumoniae tetap tinggi pada pneumonia dengan tingkat keparahan yang berat. Sementara itu, frekuensi temuan bakteri atipik menurun dan frekuensi Pseudomonas aeruginosa serta bakteri Gram-negatif lain meningkat. Penelitian ini tidak menemukan $S$. pneumoniae pada kultur bakteri. Bakteri terbanyak ditemukan adalah $S$. hominis, pada 8 dari 31 kasus. Staphylococcus hominis dan $S$. hemoliticus adalah bakteri koagulase-negatif yang merupakan bakteri Gram-positif. Keduanya adalah jenis bakteri komensal yang umum ditemukan pada kulit hewan dan manusia sehingga sering kali dianggap sebagai kontaminan dan bukan penyebab pneumonia. ${ }^{15,16} \mathrm{~S}$. hominis terkadang menyebabkan 
infeksi pada pasien dengan sistem kekebalan tubuh yang terganggu, misalnya pada pasien yang menjalani kemoterapi. ${ }^{15}$ Staphylococcus hemoliticus adalah patogen oportunistik yang paling sering terisolasi kedua setelah S. epidermidis. ${ }^{16}$ Infeksinya dapat lokal atau sistemik dan sering kali dikaitkan dengan insersi perangkat medis. Bakteri ini memiliki fenotip yang sangat tahan antibiotik dan memiliki kemampuan membentuk biofilm sehingga sulit diobati. ${ }^{16}$

Enteroccocus faesium adalah bakteri Gram-positif, alpha-hemolytic atau bakteri nonhemolitik dalam genus Enteroccocus. Bakteri ini dapat hidup komensal dalam usus manusia, tetapi dapat menjadi patogen dan menyebabkan penyakit, seperti meningitis neonatal atau endokarditis. ${ }^{17}$ E. faecium dapat menjadi bakteri penyebab ventilator associated pneumonia dan pneumonia. ${ }^{18}$

Klebsiella pneumoniae, Leclercia adecarboxylata, dan Pseudomonas fluorescens adalah bakteri batang Gramnegatif. Klebsiella pneumoniae dapat ditemukan sebagai flora normal pada mulut, kulit dan saluran cerna, tetapi dapat mengakibatkan kerusakan yang berat jika teraspirasi ke dalam paru. ${ }^{17}$ Leclercia adecarboxylata dan Pseudomonas fluorescens jarang menyebabkan penyakit pada manusia, tetapi dapat menyerang pasien dengan kekebalan tubuh yang menurun. ${ }^{19}$ Kasus pneumonia yang disebabkan oleh bakteri $L$. adecarboxylata terhitung jarang, tetapi pernah dilaporkan. ${ }^{20}$

Hasil kultur tidak berhubungan dengan keparahan pneumonia. Hal tersebut mungkin disebabkan oleh bakteri kontaminan dan riwayat pemberian antibiotik. Staphylococcus hominis dan S. hemoliticus adalah bakteri golongan koagulase-negatif yang umum ditemukan pada kulit manusia sehingga sering dianggap sebagai kontaminan. ${ }^{15,16}$ Jika keduanya tidak diperhitungkan sebagai hasil kultur positif pada pneumonia maka ditemukan hasil kultur positif pada pneumonia 1 dari 31 orang dan pada pneumonia berat 3 dari 30 orang dan tidak berbeda bermakna $(p>0,05)$. Hal tersebut berarti hasil kultur bakteri tidak berhubungan dengan keparahan pneumonia tidak berkaitan dengan faktor bakteri kontaminan.

Faktor bakteri kontaminan dapat disingkirkan jika dilakukan pemeriksaan kultur darah pada waktu yang bersamaan dengan dua lokasi yang berbeda. Pengaruh riwayat pemberian antibiotik pada penelitian kami dapat disingkirkan karena kedua kelompok tidak berbeda. Pengambilan darah untuk pemeriksaan kultur pada keadaan bakteremia mungkin menunjukkan hasil yang negatif sehingga faktor bakteremia tidak dapat diperhitungkan sebagai faktor yang menjelaskan hasil kultur yang tidak berhubungan dengan keparahan pneumonia. ${ }^{21}$ Jumlah hasil kultur bakteri pada kelompok pneumonia berat jauh lebih rendah dibandingkan penelitian terdahulu, untuk hal ini diperlukan penelitian lebih lanjut.

\section{Kesimpulan}

Keparahan pneumonia berhubungan dengan kadar prokalsitonin dan tidak berhubungan dengan hasil kultur bakteri.

\section{Daftar pustaka}

1. Rudan I, Tomaskovic L, Boschi-Pinto C, Campbell H. Global estimate of the incidence of clinical pneumonia among children under five years of age. Bull WHO 2004;82:895-903.

2. Muller F, Christ-Crain M, Bregenzer T, Krause M, Zimmerli W, Mueller B, dkk. Procalcitonin levels predict bacteremia in patients with communityacquired pneumonia: a prospective cohort trial. Chest 2010;138:121-9.

3. Assicot M, Gendrel D, Carsin H, Raymond J, Guilbaud J, Bohuon C. High serum procalcitonin concentrations in patients with sepsis and infection. Lancet 1993;341:515-8.

4. Don M, Valent F, Korppi M, Falleti E, De Candia A, Fasoli L, dkk. Efficacy of serum procalcitonin in evaluating severity of community-acquired pneumonia in childhood. Scand J Infect Dis 2007;39:129-37.

5. Boussekey N, Leroy O, Georges H, Devos P, d'Escrivan T, Guery B. Diagnostic and prognostic values of admission procalcitonin levels in community-acquired pneumonia in an intensive care unit. Infection 2005;33:257-63.

6. Tseng JS, Chan MC, Hsu JY, Kuo BI, Wu CL. Procalcitonin is a valuable prognostic marker in ARDS caused by community-acquired pneumonia. Respirology 2008;13:505-9.

7. Shah SS, Dugan MH, Bell LM, Grundmeier RW, Florin TA, Hines EM, dkk. Blood cultures in the emergency department evaluation of childhood pneumonia. Pediatr Infect Dis J 2011;30:475-9.

8. Williams DJ. Do all children hospitalized with community-acquired pneumonia require blood cultures? 
Hosp Pediatr 2013;3:177-9.

9. Cham G, Yan S, Heng BH, Seow E. Predicting positive blood cultures in patients presenting with pneumonia at an Emergency Department in Singapore. Ann Acad Med Singapore 2009;38:508-7.

10. Myers AL, Hall M, Williams DJ, Auger K, Tieder JS, Statile A, dkk. Prevalence of bacteremia in hospitalized pediatric patients with community-acquired pneumonia. Pediatr Infect Dis J 2013;32:736-40.

11. Cilloniz C, Ewig S, Polverino E, Marcos MA, Esquinas C, Gabarrus A, dkk. Microbial aetiology of communityacquired pneumonia and its relation to severity. Thorax 2011;66:340-6.

12. Paganin F, Lilienthal F, Bourdin A, Lugagne N, Tixier F, Genin R, dkk. Severe community-acquired pneumonia: assessment of microbial aetiology as mortality factor. Eur Respir J 2004;24:779-85.

13. World Health Organization. Pocket book of hospital care for children : guidelines for the management of common childhood illnesses. Edisi ke-2. WHO;2013.

14. Okimoto N, Hayashi Y, Ishiga M, Nanba F, Kishimoto M, Yagi S, dkk. Procalcitonin and severity of community-acquired pneumonia. J Infect Chemother 2009; 15:426-7.
15. Nagase N, Sasaki A, Yamashita K, Shimizu A, Wakita Y, Kitai S, dkk. Isolation and species distribution of staphylococci from animal and human skin. J Vet Med Sci 2002;64:245-50.

16. de Allori MC, Jure MA, Romero C, de Castillo ME. Antimicrobial resistance and production of biofilms in clinical isolates of coagulase-negative Staphylococcus strains. Biol Pharm Bull 2006;29:1592-6.

17. Ryan KJ, Ray CG, Sherris JC, penyunting. Sherris medical microbiology: an introduction to infectious diseases. Edisi ke-4. New York: McGraw-Hill; 2004.

18. Portero JL, Porcel JM, Ruiz A, Rubio-Caballero M. Community-acquired pneumonia caused by Enterococcus faecium. Med Clin (Barc) 1994;102:316-7.

19. Hess B, Burchett A, Huntington MK. Leclercia adecarboxylata in an immunocompetent patient. J Med Microbiol 2008;57:896-8.

20. Eiland EH, 3rd, Siddiqui H, Goode AM, Leeth SD. Pneumonia due to multidrug-resistant Leclercia adecarboxylata. Am J Health Syst Pharm 2013; 70:940-1.

21. Theodosia R, Siadi PP, Naning R. Validity of bacterial pneumonia score for predicting bacteremia in children with pneumonia. Paed Ind 2011;51:322-6 